\title{
Transition from Face-to-Face Teaching to Online Teaching in Times of Pandemic
}

\author{
Danielle Morin
}

\begin{abstract}
The education systems around the world have had to adapt quickly to find ways to offer university programs remotely in the face of the Covid 19 pandemic. Without the proper preparation and sufficient knowledge, instructors learned to teach online during the Winter 2020 semester to allow students to complete their courses when campuses suddenly closed as a safety measure. Normally many weeks of preparation would have been necessary to redesign a course to be efficiently offered online. This paper studies some aspects of the transition from Face to Face teaching in the Fall 2019 semester to Face to face / Online teaching in the Winter of 2020 (beginning of the pandemic) to completely Online teaching in the Fall 2020. This transition is examined in a Managerial Analytics course offered in the first semester of an MBA program at a Canadian University. A survey administered at the end of each semester reveals different levels of students' anxiety, modification in the communication tools utilized, changes in intensity of weekly study hours and expected recollection of the material learned in the course, a year after completion. Additional variations are also observed by gender.
\end{abstract}

Index Terms-Online teaching, face-to-face teaching, anxiety, means of communication.

\section{INTRODUCTION}

University teaching has changed so much over the years that people who graduated twenty years ago would not recognize it. Most instructors are offering many online learning tools and additional flexibility. Many have moved their teaching completely online, and some programs do not require students to be in the same country as the institution offering the program. This wave will continue for the years to come, with the younger generation of professors already familiar and comfortable with the required technology.

However, for some professors, the physical contact with their students is still very important and to be maintained. Research shows that many students if given the choice, would select in class teaching. Two large surveys were conducted in 2019, by the EDUCAUSE Center for Analysis and Research with the participation of more than 40,000 students and 9,500 faculty members across more than 110 institutions in the US. The results showed that $70 \%$ of students prefer mostly or completely face-to-face teaching, and $73 \%$ of instructors prefer face-to-face teaching. Only $9 \%$ of both students and faculty surveyed preferred mostly or completely online education. [1] Other research concluded that online courses fail in the lack of students' motivation and

Manuscript received May 14, 2021; revised September 23, 2021.

D. Morin is with the Department of Supply Chain and Business Technology Management, John Molson School of Business, Concordia University, 1450 De Maisonneuve West, Montreal, QC H3G 1M8, Canada (e-mail: Danielle.Morin@Concordia.ca). memory development [2] while others did not find any significant difference in students' performance in either course delivery. [3] The literature on this dilemma is extensive. ([4]-[8]) Because the technology is easily available, many professors adopt a blended teaching approach with face-to-face complemented with several online learning tools.

The Coronavirus has changed the world; it has changed our daily lives. Its impact has been most important in education when suddenly in the winter 2020 semester, campuses closed for health reason and within a few days, all teaching activities became virtual. Without any preparation for this challenge, professors teaching face-to-face suddenly had to finish the semester completely online. Many quickly realized that online teaching is not simply replicating what was done in class to the virtual environment. The pedagogical approach is very different and more challenging. ([9]-[11]) It normally takes serious planning to design the proper way to deliver a course online. Ways to present material asynchronously, cannot be done the same way as it would be done in class. In the virtual environment, the instructor has to find ways to motivate students, try to assess their understanding of the material and provide additional support. Most universities have encouraged the creation of online courses for many reasons including some financial benefits and this was happening very slowly until the shock of the coronavirus pandemic.

The last few months have been unique in the sense that it was an accelerated transition from face-to-face to online learning in a record time. Many students have used university computers to do much of their work, but the new situation made this option very difficult. Therefore, many factors could hinder students' learning in a virtual environment such as the unavailability of high speed internet, and the lack of a quiet space to study. [12]

This abrupt transition to online learning was not always well received by students. An online survey of 380 students done at The University of Boumerdes in Algeria revealed that students have a negative perception of online learning and would prefer to maintain the traditional way of teaching even during the coronavirus pandemic. [13] Results of another survey in Tuzla University in the Bosnia Herzegovina Federation using an online learning attitude scale with 130 student teachers concluded that in spite of the challenges, this transition to online could be considered a positive step in the success of the teaching profession and the student teacher's attitudes towards online learning during COVID-19 are positive. [14] Many similar studies were conducted around the world.

Unfortunately, many mental issues, loneness and anxiety have been hard on many people and in students in particular 
because of the sudden change in their lives. [15] What happened in the Winter 2020 semester could be referred to as "an emergency remote teaching" made essential on instructors and students, but not easy nonetheless and requiring an adaptation period. [16]

Other studies have shown that data obtained from a student course satisfaction survey collected in two universities during the 2020 summer term (June through August), reveal that students have been more resilient than is often assumed. [17] Another survey done on 1500 students at one of the largest public institutions in the United States, revealed that $25 \%$ of students increased their study time by more than 4 hours per week due to COVID-19, while another $25 \%$ decreased their study time by more than 5 hours per week, probably due to socioeconomic factors. [18]

The focus of this paper is to identify the impact of the change in teaching delivery on some aspects of anxiety, and attitudes over three key semesters, before the pandemic, during the beginning of the pandemic and during the pandemic. Moving to online teaching about two third into a semester is very stressful for both students and instructors. Factors such as the communication media used, the retention rates of the material being learned, the amount of time spent studying per week will be investigated.

\section{Methodology}

\section{A. The Semesters}

To study the impact of the abrupt change in teaching delivery due to the Coronavirus, three academic semesters and a course to collect data from have been identified. Table I summarizes the main characteristics of each semester.

Three semesters are considered for this research: Fall 2019, Winter 2020 and Fall 2020. The Fall 2019, from September to December 2019 is a normal in-class semester with face to face classroom teaching, in person office hours with the professor and tutor, complemented with several Youtube videos and other learning tools on the Moodle platform. The Winter 2020 semester, from January to April 2020, started with the same pedagogical approach, but after the $9^{\text {th }}$ week, because of the pandemic, the course reverted to completely online using Zoom and the Moodle platform. All remaining lectures, office hours with professor and tutor, exams and assignments were offered entirely online. This abrupt transition to online teaching, was not easy for professors, who had to learn in a few days, the new technology from home and for students who became isolated at their place, only connected to their university community remotely. The course under study is not offered in the Summer months. The third semester under consideration, Fall 2020, from September to December 2020 was offered completely online. International students could not enter Canada and started the MBA program in their home country. Different time zones became a big challenge for the professor and students.

\section{B. The Course}

A mandatory Managerial Analytics course offered in the first semester on an MBA program at a Canadian University is used for this research. Students from different background and origin must take the course following a preparatory online seminar offered about one month prior to the beginning of the semester. This seminar ensures that students have a certain level of quantitative ability before the first MBA semester. The same professor teaches the course for the last three years and prior to the pandemic, used an in-class teaching approach, supported by online material and activities, with face-to-face office hours and exams written in class.

\section{The Transition}

From the beginning of the pandemic, classroom face-to-face teaching became live Zoom sessions that were recorded and made available to be watched again. Office hours and tutorials were also done live on Zoom. Assignments were posted on the Moodle platform and completed assignments in PDF format also submitted on Moodle.

TABLE I: DESCRIPTION OF SEMESTERS

\begin{tabular}{|c|c|c|c|}
\hline Semesters & Fall 2019 & Winter 2020 & Fall 2020 \\
\hline Format & On Campus & $\begin{array}{l}\text { On Campus for the first } 9 \text { lectures followed } \\
\text { by Online teaching only, no campus access }\end{array}$ & $\begin{array}{l}\text { Online teaching only. No campus access } \\
\text { and no entrance to the country for } \\
\text { students from abroad. }\end{array}$ \\
\hline Delivery & $100 \%$ Face-to-Face & $\begin{array}{l}70 \% \text { Face-to-face and 30\% Live Zoom } \\
\text { sessions + recorded }\end{array}$ & 100\% Live Zoom sessions, + recorded \\
\hline Professor Office Hours & $100 \%$ Face-to-Face & $70 \%$ Face-to-Face $-30 \%$ on Zoom & $100 \%$ on Zoom \\
\hline Tutor Office hours & $\begin{array}{l}\text { Face-to-Face two hours per } \\
\text { week on Campus }\end{array}$ & $\begin{array}{l}70 \% \text { Face-to-Face }-30 \% \text { on Zoom, no } \\
\text { campus access }\end{array}$ & $\begin{array}{l}\text { Two Zoom sessions, early in the } \\
\text { morning and in the evening for different } \\
\text { Time Zones. }\end{array}$ \\
\hline $\begin{array}{l}\text { Solutions to End of } \\
\text { Chapter problems }\end{array}$ & $\begin{array}{l}\text { Solutions posted on the } \\
\text { course platform Moodle }\end{array}$ & $\begin{array}{l}\text { Solutions posted on the course platform } \\
\text { Moodle }\end{array}$ & $\begin{array}{l}\text { Solutions posted on Moodle and Zoom } \\
\text { recording of the solutions }\end{array}$ \\
\hline Midterm exam Review & None & None & Zoom live review sessions \\
\hline Final exam review & None & Zoom Live Review session & Zoom Live review session and recorded \\
\hline Midterm Exam & In class & In class & Online \\
\hline Final Exam & In class with laptop & $\begin{array}{l}\text { Completely done online from remote } \\
\text { locations }\end{array}$ & $\begin{array}{l}\text { Completely done online from home } \\
\text { country }\end{array}$ \\
\hline Weekly quizzes & None & None & $\begin{array}{l}\text { Six online multiple choice quizzes at the } \\
\text { end of each chapter }\end{array}$ \\
\hline
\end{tabular}


The midterm exam and the final exam that used to be done in class are done online. The exams are now split into two parts: the first part is made up of multiple choice questions on Moodle where a number of randomly selected questions is assigned to each student. The second part is a Word file with the questions to be answered and the corresponding Excel data file. A time limit to complete the two parts of the exam is set. A group of students from the Middle East and India were allowed to write the final exam at a different time slot to accommodate different time zones. Writing non-proctored exams online could make cheating possible, but the professor used an honor system and rely on students' honesty. There was no evidence of cheating. For the Fall 2020 semester, when the course was offered completely online, additional support activities and resources were included in the course, such as six short quizzes to be taken after each chapter, live Zoom review sessions, recorded end of chapter solution presentation and Zoom office hours at two different convenient times.

\section{The Questionnaire}

A survey instrument used in [19] is utilized to collect data at the end of each semester. The questionnaire contains several parts: demographics, anxiety, means of communication, hours of study for the course and the estimate of the proportion of material expected to be remembered one year after course. Data is analyzed by gender and overall.

\section{RESULTS}

\section{A. Demographics}

Data collected at the end of each of the three semesters of interest resulted in 60 respondents in the Fall 2019, 49 in the Winter 2020 semester and 46 in the Fall 2021 semester, of which $40 \%, 36.7 \%$ and $36.4 \%$ are female respondents respectively.

\section{B. Anxiety}

Respondents were presented with nine situations and were asked to assess their level of Anxiety on scale from 1 to 10 , where 1 corresponds to "No anxiety" and 10 corresponds to "Extreme anxiety". Table II contains the average level of Anxiety for each statement, for Fall 2019 (prior to the pandemic), Winter 2020 (beginning of the pandemic) and Fall 2020 (during the pandemic), overall and by gender.

Results presented are descriptive and no tests of significance were performed. Surprisingly, overall, for all situations, the highest level of Anxiety is always observed in the Fall 2019 semester, when the course was offered in-class prior to the pandemic and the lowest levels when the course is partially or fully online. In general, the average levels tend to decrease as the course moves to completely online. This may not be what could have been expected. This could potentially be attributed to the additional resources and learning activities offered to compensate for the distance.

The first two statements about level of Anxiety with exams in general, being closed book or open book exam: A1: Before a closed book exam and A2: Before an open book exam, have overall their lowest average levels of anxiety in the Winter semester, which was the semester where the pedagogy was modified abruptly. We observe a very small increase for the Fall 2020 semester, but still lower than the in-class situation. This could be due to a false sense of confidence because of the advantage of doing exams remotely, without supervision and all possible source of information available.

The following four situations refers to Analytics exams: A3: When studying for an Analytics exam, A4: Waking up the day of an Analytics exam and A5: Before writing an Analytics exam and A6: While writing an Analytics exam. The highest overall average level of anxiety for those four situations is always found at the pre-pandemic semester. The anxiety level is lower when the final exam is done virtually, possibly for the same reason as above, where there could be a false sense of confidence. It is to be noted that the survey was done prior to students obtaining their final grades in the course.

TABLE II: AVERAGE LEVEL OF ANXIETY ACROSS SEMESTERS BY GENDER

\begin{tabular}{|c|c|c|c|c|c|c|c|c|c|}
\hline \multirow[b]{2}{*}{ Situations } & \multicolumn{3}{|c|}{ Overall } & \multicolumn{3}{|c|}{ Female Respondents } & \multicolumn{3}{|c|}{ Male Respondents } \\
\hline & $\begin{array}{c}\text { Fall } \\
2019\end{array}$ & $\begin{array}{l}\text { Winter } \\
2020\end{array}$ & $\begin{array}{c}\text { Fall } \\
2020\end{array}$ & $\begin{array}{c}\text { Fall } \\
2019\end{array}$ & $\begin{array}{l}\text { Winter } \\
2020\end{array}$ & $\begin{array}{c}\text { Fall } \\
2020\end{array}$ & $\begin{array}{c}\text { Fall } \\
2019\end{array}$ & $\begin{array}{c}\text { Winter } \\
2020\end{array}$ & $\begin{array}{c}\text { Fall } \\
2020\end{array}$ \\
\hline A1: Before a closed book exam & 7.050 & 6.245 & 6.422 & 7.750 & 6.500 & 7.235 & 6.583 & 6.097 & 5.929 \\
\hline A2: Before an open book exam & 5.533 & 5.327 & 5.364 & 6.000 & 6.389 & 5.471 & 5.222 & 4.710 & 5.296 \\
\hline $\begin{array}{l}\text { A3: When studying for an Analytics } \\
\text { exam }\end{array}$ & 5.767 & 5.000 & 4.978 & 6.292 & 5.444 & 5.412 & 5.417 & 4.733 & 4.714 \\
\hline $\begin{array}{l}\text { A4: Waking up the day of an Analytics } \\
\text { exam }\end{array}$ & 5.733 & 5.020 & 4.867 & 6.333 & 5.278 & 5.824 & 5.333 & 4.871 & 4.286 \\
\hline A5: Before writing an Analytics Exam & 6.350 & 5.959 & 6.000 & 6.792 & 6.500 & 6.647 & 6.056 & 5.645 & 5.607 \\
\hline A6: While writing an Analytics exam & 6.217 & 5.980 & 5.511 & 6.958 & 6.333 & 6.176 & 5.722 & 5.774 & 5.107 \\
\hline $\begin{array}{l}\text { A7: Answering Analytics multiple } \\
\text { choice questions }\end{array}$ & 6.000 & 6.082 & 5.133 & 6.917 & 6.222 & 5.882 & 5.389 & 6.000 & 4.679 \\
\hline A8: Interpreting statistical results & 5.233 & 4.653 & 4.311 & 6.000 & 4.944 & 5.176 & 4.722 & 4.484 & 3.786 \\
\hline $\begin{array}{l}\text { A9: Determining whether to reject the } \\
\text { null hypothesis }\end{array}$ & 4.700 & 4.163 & 3.733 & 5.333 & 4.444 & 4.118 & 4.278 & 4.000 & 3.500 \\
\hline
\end{tabular}


However, there could be another factor contributing to lower levels of anxiety during the two semesters of the pandemic which is the fact that many universities have offered students the option to replace their poor grades with a "pass grade" and therefore not jeopardize their average GPA. Another option was offered to students during the pandemic, which is to replace "Fail grade" with a "discontinued" grade which again does not affect the GPA.

The statement A7: Answering Multiple choice questions in an Analytics exam shows higher level of anxiety in the first semester. The average anxiety went down in the third semester which could be due to the introduction six multiple choice review quizzes to be taken after each chapter. Multiple choice questions are often used to test theory and short calculations as part of midterm and final exams and students do not perform very well in them. Because of the challenges of the virtual environment additional training measure were put in place and most probably lowered students' anxiety. This support should probably be maintained when the pandemic is over.

The last two statements A8: Interpreting statistical results and A9: Determining whether to reject the null hypothesis, are not always well understood but the average level of anxiety is decreasing towards the Fall 2020 semester. This is probably also due to all the additional support offered.

Table II also shows that some patterns of results are different according to gender. First of all, the average level of anxiety for Female respondents is always higher than that of Male respondents for each semester and each statement. This is the case for A1: Before an open book exam, et A2: Before an open book exam, the average anxiety level is higher for Female respondents for every semester, even a strong increase in the Fall 2020. Another different behavior is observed for statements A6: While writing an Analytics, and A7: Answering multiple choice questions in an Analytics exam, again for Female respondents the average level of anxiety is higher for all semesters but decreasing in time. Male respondents, while having lower average, show a pattern of slight average increase for the early pandemic semester which was not observed for Female students.

\section{Means of Communication}

The pandemic that hit the world has had impacts on several components of educational programs. In particular, in the MBA program, because of group projects, team work and study groups, efficient communication tools became crucial. Table III shows that the proportion of students using specific communication tools has changed over the semesters.

TABLE III: MEANS OF COMMUNICATIONS BETWEEN STUDENTS BY SEMESTER

\begin{tabular}{lccc}
\hline \hline Means & Fall 2019 & Winter 2020 & Fall 2020 \\
\hline WhatsApp & $93.33 \%$ & $75.51 \%$ & $97.83 \%$ \\
Zoom & $0.00 \%$ & $46.94 \%$ & $78.26 \%$ \\
Email & $76.67 \%$ & $55.10 \%$ & $63.04 \%$ \\
Phone calls & $43.33 \%$ & $48.98 \%$ & $23.91 \%$ \\
Text Messaging & $30.00 \%$ & $34.69 \%$ & $21.74 \%$ \\
Microsoft Team & $3.33 \%$ & $12.24 \%$ & $6.52 \%$ \\
Facebook & $6.67 \%$ & $8.16 \%$ & $4.35 \%$ \\
Google & $0.00 \%$ & $6.12 \%$ & $2.17 \%$ \\
Face-to-face & $80.00 \%$ & $51.02 \%$ & $2.17 \%$ \\
\hline No. students & 60 & 49 & 46 \\
\hline \hline
\end{tabular}

It can be observed that the proportion of students using specific tools has changed but WhatsApp remains the most popular tool of communication among students for all three semesters. Zoom that was not used in the Fall 2019 semester, became in the Fall 2020 the second most popular tool among students. We note that as Zoom's popularity increases in the Winter 2020 semester, email messaging and Whatsapp dropped and raised again in the third semester.

It seems that students were trying to assess if the new tools Zoom and Microsoft Team could replace email messaging and WhatsApp. The last semester shows that Zoom could not replace everything and some went back to WhatsApp and emails. Phone calls went from $43.33 \%$ to $23.91 \%$ in one year, which is mostly due to long distance costs. Text Messaging went from $30.00 \%$ to $21.74 \%$ during the same period. Since Face to face communication is no longer possible with online classes, the proportion went from $80.00 \%$ to $2.17 \%$.

\section{Hours of Study}

Respondents were asked to indicate their average number of hours of study per week, they have dedicated to the Analytics course, either less than 2 hours, between 2 and 4 hours, between 4 and 6 hours or more than 6 hours. Table IV gives the proportion of respondents who fall in each category of the number of hours of study with each row totals $100 \%$. The last column of the table corresponds to the approximate average number of hours of study for each row, using as an upper limit for the category " $>6$ ", 10 hours.

TABLE IV: HOURS OF STUDY PER WEEK, BY GENDER AND SEMESTER

\begin{tabular}{|c|c|c|c|c|c|c|}
\hline \multirow[b]{2}{*}{ Semesters } & \multirow[b]{2}{*}{ Gender } & \multicolumn{5}{|c|}{ Hours per week } \\
\hline & & $<2$ & 2 to 4 & 4 to 6 & $>6$ & Average \\
\hline Fall 2019 & Female & $8.33 \%$ & $50.00 \%$ & $29.17 \%$ & $12.50 \%$ & 4.042 \\
\hline \multirow{2}{*}{$\mathrm{N}=60$} & Male & $8.33 \%$ & $58.33 \%$ & $19.44 \%$ & $13.89 \%$ & 3.916 \\
\hline & Total & $8.33 \%$ & $55.00 \%$ & $23.33 \%$ & $13.33 \%$ & 3.966 \\
\hline \multirow[t]{3}{*}{ Winter 2020} & Female & $0.00 \%$ & $33.33 \%$ & $38.89 \%$ & $27.78 \%$ & 5.167 \\
\hline & Male & $6.45 \%$ & $64.52 \%$ & $16.13 \%$ & $12.90 \%$ & 3.839 \\
\hline & Total & $4.08 \%$ & $53.06 \%$ & $24.49 \%$ & $18.37 \%$ & 4.327 \\
\hline \multirow[t]{3}{*}{ Fall 2020} & Female & $11.76 \%$ & $29.41 \%$ & $41.18 \%$ & $17.65 \%$ & 4.471 \\
\hline & Male & $6.90 \%$ & $24.14 \%$ & $41.38 \%$ & $27.59 \%$ & 5.064 \\
\hline & Total & $8.70 \%$ & $26.09 \%$ & $41.30 \%$ & $23.91 \%$ & 4.848 \\
\hline
\end{tabular}


TABLE V: PROPORTION OF RETENTION OF INFORMATION, BY GENDER AND SEMESTER

\begin{tabular}{|c|c|c|c|c|c|c|}
\hline & & \multicolumn{4}{|c|}{ Proportion of Retention } & \multirow[b]{2}{*}{ Average } \\
\hline Semesters & Gender & $<40 \%$ & $40 \%-60 \%$ & $60 \%-80 \%$ & $>80 \%$ & \\
\hline Fall 2019 & Female & $16.67 \%$ & $29.17 \%$ & $41.67 \%$ & $12.50 \%$ & $58.34 \%$ \\
\hline \multirow{2}{*}{$\mathrm{N}=60$} & Male & $5.56 \%$ & $19.44 \%$ & $47.22 \%$ & $27.78 \%$ & $68.89 \%$ \\
\hline & Total & $10.00 \%$ & $23.33 \%$ & $45.00 \%$ & $21.67 \%$ & $64.67 \%$ \\
\hline \multirow[t]{3}{*}{ Winter 2020} & Female & $5.56 \%$ & $27.78 \%$ & $44.44 \%$ & $22.22 \%$ & $66.11 \%$ \\
\hline & Male & $3.23 \%$ & $16.13 \%$ & $45.16 \%$ & $35.48 \%$ & $72.26 \%$ \\
\hline & Total & $4.08 \%$ & $20.41 \%$ & $44.90 \%$ & $30.61 \%$ & $70.00 \%$ \\
\hline \multirow[t]{3}{*}{ Fall 2020} & Female & $11.76 \%$ & $29.41 \%$ & $41.18 \%$ & $17.65 \%$ & $61.77 \%$ \\
\hline & Male & $6.90 \%$ & $37.93 \%$ & $31.03 \%$ & $24.14 \%$ & $63.79 \%$ \\
\hline & Total & $8.70 \%$ & $34.78 \%$ & $34.78 \%$ & $21.74 \%$ & $63.04 \%$ \\
\hline
\end{tabular}

Table IV shows that the overall proportion of students who responded that they study more than 6 hours per week for the Analytics course is increasing each semester. From $13.33 \%$ in Fall 2019, to $18.37 \%$ in Winter 2020 to $23.91 \%$ in the Fall 2020 semester. Similarly, the proportion of students who study more than 4 hours per week for the course is increasing each semester, from $36.66 \%(23.33 \%+13.33 \%)$ to $42.86 \%$ $(24.49 \%+18.37 \%$ to $65.22 \%(41.30 \%+23.91 \%)$. Those results confirm what is often heard in the media that the workload is increasing. The approximated overall average number of hours of study per week has also increased from 3.966 to 4.327 to 4.848 .

On average in the Fall 2019 and Winter 2020 semester, Female students have a slightly higher average hours of study. However, in the fully online session, Fall 2020, Male students show a higher average.

\section{E. Information Retained}

Respondents were also asked to assess the percentage of information learned in the Analytics course that they expect to remember in one year by selecting: Less than $40 \%, 40 \%$ to $60 \%, 60 \%$ to $80 \%$ and more than $80 \%$. This is an important fact because the Analytics course is taken in the first semester of the MBA program.

Table V shows that overall, $66.67 \%(45 \%+21.67 \%)$ of respondents in the Fall 2019 semester expect to remember more than $60 \%$ of the material learned in the course. In the Winter 2020 semester, $75.51 \%(44.90 \%+30.61 \%)$ expect to remember more than $60 \%$ and in the Fall 2020, this number is down to $56.52 \%(34.78 \%+21.74 \%)$. This seems to indicate that material learned in a virtual environment is not expected to be remembered as much as what is learned in class or in a mixed model. Surprisingly, in the Winter 2020, respondents had the highest confidence in their future recollection of the material learned, overall and by gender. In all three semesters, male respondents were more confident in their abilities to remember the material, with $12.50 \%$ of Female and $27.78 \%$ of Male students expect to remember more than $80 \%$ of the material learned in the Fall 2019, 22.22\% and 35.48\% in Winter 2020 and $17.65 \%$ and $24.14 \%$ in Fall 2020. The average amount of retention is approximated in the last column.

The highest proportion of information expected to be retained corresponds to the Winter 2020 semester, the semester when the pandemic caused universities to close and abruptly revert to online teaching. This could be justified by the resources put in place to support students during the difficult times. Male respondents expect to remember larger amount of information.

\section{CONCLUSION}

The transition from in-class teaching to in-class/distance teaching to completely online teaching has had an impact on several aspects of the students' university experience. The levels of anxiety across semesters have been different. Interestingly, the levels of anxiety were at their highest during the in-class semester and the lowest during online teaching. It seems that all the support measures put in place have help students during these difficult times. It is certainly important to review the learning support tools developed during this pandemic and possibly be retained when life gets back to normal.

In a virtual environment, communication between students became more complicated, but necessary. Whatsapp which was highly used prior to the pandemic, continued to be the most important means of communication among students most probably because of the ease of use and good manipulation of documents. Zoom which was not used in the Fall 2019 semester, became very important by Fall 2020. It was also used by most instructor to deliver online lectures. The use of email messaging is the third option. Phone calls and text messaging are used by less than $25 \%$ of students in the virtual semester and Face to face communication is not a viable option for online courses.

The pandemic that hit the world forced an abrupt movement towards distance learning. Students had to dedicate more studying hours for their courses, even if professors did not change the level of difficulty of the course or the number of deliverables. The challenges often lie in the environment not always conducive to studying in times of forced confinement. For some students, mental illness issues and isolation made the situation even more difficult.

The survey also revealed that the estimated proportion of material learned in the course and retained later is the highest for Female and Male students during the Winter 2020 semester which corresponds to the beginning of the pandemic. These results could be explained by the many support tools put in place to help students finished the semester in a stressful period. Several virtual Office hours where students could simply be in the Zoom session and listen to other 
students asking questions, virtual review sessions and additional tutorials proved to be helpful. These additional support tools should probably be maintained when we come back to in-class teaching as they appeared to be very useful.

Overall this period of pandemic has forced professors to think outside of the box to develop new teaching approaches which turned out to be successful and may be incorporated in their teaching when in-class teaching will resume. Students have also found ways to adapt to the challenging situation.

\section{CONFLICT OF INTEREST}

The author declares no conflict of interest.

\section{REFERENCES}

[1] R. Koenig, "Most students and faculty prefer face-to-face instruction, EDUCAUSE surveys find," Digital Learning in Higher Education, 2019.

[2] SETHUGHES. (2020). Why traditional classroom learning is better than online courses. [Online]. Available: https://owlcation.com/academia/Why-Traditional-Classroom-Learnin g-is-Better-than-Online-Courses

[3] J. Paul and F. Jefferson, "A comparative analysis of student performance in an online vs. face-to-face environmental science course from 2009 to 2016," Frontiers in. Computer Science, vol. 1, no. 7 , 2019.

[4] F. Tanyel and J. Griffin, "A ten-year comparison of outcomes and persistence rates in online versus face-to-face courses," 2014.

[5] J. T. Mann and S. R. Henneberry, "Online versus face-to-face: students' preferences for college course attributes," Journal of Agriculture and Applied Economics, vol. 46, pp. 1-19, 2014.

[6] D. Morin, H. S. Fard, and R. G. Saade, "Understanding online learning based on different age categories," Issues in Informing Science and Information Technology, vol. 16, pp. 307-317, 2019.

[7] D. Morin, R. G. Saade, and S. Dadras, "Beliefs and confidence in online learning," TOJET: The Turkish Online Journal of Educational Technology, November 2018, Special Issue for INTE-ITICAM-IDEC, vol. 1, pp. 244-253, 2018.

[8] D. Morin, J. D. E. Thomas, R. G. Saade, and D. Petrachi, "Survey of online user perspectives and gender," International Journal of Management and Applied Science (IJMAS), vol. 4, no. 8, pp. 86-93, 2018.

[9] K. Brouse, "How online teaching should differ from face-to-face instruction," Teaching Strategies, August 7, 2020.

[10] C. Nobre. (2018). Teaching online vs teaching face-to-face. Cambridgeenglish.org. [Online]. Available: https://ugc.futurelearn.com/uploads/files/d6/cd/d6cd9dc1-efbe-4dfd-8 1d4-ccc283de76a1e/Teaching_Online_Vs_Teaching_Face_to_Face_F inalR2.pdf
[11] Online vs. face-to-face learning. University of Illinois Springfield. [Online]. Available: https://www.uis.edu/online/getting-started/learning-online/online-vs-f ace-to-face-learning/

[12] C. B. Mpungose, "Emergent transition from face-to-face to online learning in a South African University in the context of the Coronavirus Pandemic," Humanities \& Social Sciences Communications, vol. 7, article 113, 2020.

[13] D. Blizak, S. Blizak, O. Bouchenak, and K. Yahiaoui, "Students' perceptions regarding the abrupt transition to online learning during the COVID-19 pandemic: Case of Faculty of Chemistry and Hydrocarbons at the University of Boumerdes - Algeria," Journal of Chemical Education, vol. 97, no. 9, pp. 2466-2471, 2020.

[14] K. Nachimuthu, "Student teacher's attitude towards online learning during Covid-19," International Journal of Advanced Science and Technology, vol. 29, no. 6, pp. 8745-8749, 2020.

[15] A. Packham, "I was just sat in my room all day: Lonely students seek mental health support," The Guardian, October, 28, 2020.

[16] A. Bozkurt and R. C. Sharma, "Emergency remote teaching in a time of global crisis due to Coronavirus Pandemic," Asian Journal of Distance Education, vol. 15, no. 1, pp. i-vi, 2020.

[17] K. Lee, M. Fanguy, X. S. Lu, and B. Bligh, "Student learning during COVID-19: It was not as bad as we feared," Distance Education, vol. 42, no.1, pp. 164-172, 2021

[18] E. M. Aucejo, J. F. French, M. P. U. Araya, and B. Zafar, "The impact of COVID-19 on student experiences and expectations: Evidence from a survey," NBER Working Paper No. 27392, June 2020.

[19] D. Morin, "The impact of the pandemic on attitudes and perceptions of students in an MBA analytics course," INTED 2021 Proceedings.

Copyright $\odot 2022$ by the authors. This is an open access article distributed under the Creative Commons Attribution License which permits unrestricted use, distribution, and reproduction in any medium, provided the original work is properly cited (CC BY 4.0).

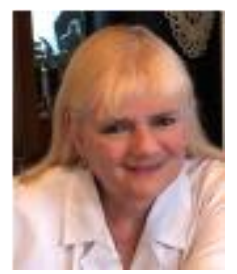

Danielle Morin is a professor of Managerial Analytics at the John Molson School of Business at Concordia University in Montreal, Canada. She holds a PhD in Statistics from McGill University, Montreal, Canada. She teaches Managerial Analytics at the undergraduate and graduate levels, especially in the MBA program She has published her research in refereed journals and international conferences. She also has over thirteen years of experience as senior university administrator as Associate Dean and Vice-Provost. Her current research focuses on the impact of technology on student's learning.

Dr. Morin has been awarded several awards for her teaching and leadership excellence, such the YWCA Women of Excellence Award in Education, the Alumni Teaching Award, the Dean's Award and the President's Award for Teaching Excellence, and the Concordia University Academic Leadership Award. She is also member of the Order of Chartered Administrators of Quebec (ADMA). 